\title{
Aberrant expression of CD133 in non-small cell lung cancer and its relationship to vasculogenic mimicry
}

\author{
Shiwu Wu, Lan Yu, Danna Wang, Lei Zhou, Zenong Cheng, Damin Chai, Li Ma and Yisheng Tao*
}

\begin{abstract}
Background: To investigate on expressions and clinical significances of CD133 protein and vasculogenic mimicry (VM) in primary non-small cell lung cancer (NSCLC).

Methods: The specimens of NSCLC from 305 Chinese patients with follow-up were analyzed for CD133 protein expression and VM by immunohistochemical and histochemical staining.

Results: In NSCLC, positive rates of $48.9 \%$ and $35.7 \%$ were obtained for CD133 and VM, respectively. The VM and expression of CD133 were significantly higher in carcinoma than in normal. There were a positive relationship between the VM and expression of CD133 and the tumor grade, lymph node metastasis and clinical stage (all $\mathrm{P}<0.05)$. The overall mean survival time of the patients with CD133 and VM positive expression was lower than that of patients with negative expression. Microvessel density (MVD) was positive corresponded with the grade, lymph node metastasis and clinical stage (all $P<0.05$ ). The overall mean survival time of the patients with MVD $\geq 22$ 's group was shorter than that of patients with MVD<22's group. Pathological-tumor-node-metastasis (pTNM) stage, positive expression of CD133 and VM, postoperative therapy and MVD were independent prognostic factors of NSCLC $(\mathrm{P}<0.05)$. Immunohistochemistry revealed an important intratumoral heterogeneity in all four CD133 expression profiles.

Conclusions: VM, MVD and expression of CD133 are related to differentiation, lymph node metastasis, clinical stage, and prognosis. It is suggested that CD133, VM and MVD should be considered as a potential marker for the prognosis.
\end{abstract}

\section{Background}

Lung cancer is among the most common form of cancer of the respiratory system with an estimated incidence of approximately 220,000 cases in the USA [1], and is the leading cause of cancer-related mortality worldwide, with nearly 1.4 million deaths each year [2], and non-small cell lung cancer (NSCLC) accounts for nearly $85 \%$ of all cases of lung cancer [1]. Worldwide, NSCLC is the most common form of cancer with overall 5-year survival rate of less than $20.0 \%$ as most patients are diagnosed late and are unsuitable for curative surgery. A major problem in finding treatments is the frequent resistance to drugs which emerges. This is linked to the development and maintenance of small population of tumor cells, termed

\footnotetext{
*Correspondence: tys101041@126.com

Department of Pathology, the First Affiliated Hospital of Bengbu Medical College, Bengbu Medical College, Bengbu 233000, Anhui Province, China
}

cancer stem cells (CSCs) or tumor-initiating cells (TIC). These cells have been implicated in self-renewal, progression, and therapy-resistance in multiple solid cancers and high tumorigenicity [3-13]. A commonly CSCs marker is CD133, also known as prominin-1, a $120 \mathrm{kDa}$ five transmembrane domain cell surface glycoprotein, is originally described as a surface antigen specific for human hematopoietic stem and progenitor cells $[14,15]$. CD133 is overexpressed in various solid tumors, including brain [16], endometrial cancer [17], kidney [18], lung [19], liver [20], gastric [21,22], colon [23], pancreas [24], breast [25], skin [26] and prostate [27].

About tumor blood supply, the traditionally much attention has been focused on the role of angiogenesis [28]. Recently, Maniotis [29] and his coworkers had described an angiogenesis-independent pathway called "vasculogenic mimicry (VM)", a new phenomenon in which highly 
aggressive human melanoma cell mimic endothelial cells and form vascular channel-like structures to convey blood without the participation of endothelial cells. VM consists of three formations: the plasticity of malignant tumor cells, remodeling of the extracellular matrix (ECM), and the connection of the VM channels to the host microcirculation system [30-33]. Later, in many aggressive tumors, including breast carcinoma [34], glioma [35], hepatocellular carcinoma [36], clear cell renal cell carcinoma [37], laryngeal squamous cell carcinoma [38], ovarian carcinoma [39], gastric adenocarcinoma [40] and prostate carcinoma [41], have been described. VM is associated with poor prognosis in tumor patients. The relationship between CD133 and VM in NSCLC has not yet been explored. In this study, we performed an immunohistochemical investigation to explore the role of the CD133 and VM in chinicopathology and prognosis in 305 cases of NSCLC.

\section{Methods}

\section{Biopsy specimens}

Paraffin embedded sections of 305 NSCLCs and 30 distal normal lung tissues were obtained from the Department of Pathology, the First Hospital Affiliated to Bengbu Medical College between 2003 and 2006 (Patients who had received preoperative chemotherapy or radiotherapy were excluded). This study was approved by the ethical committee of the First Hospital Affiliated to Bengbu Medical College before its start. The age of the patients ranged from $26-82$ years, the median age was 59.8 years. Two hundred thirty-three were males and seventy-two were females. Among the 305 cases, 248 were to postoperative therapy (routine chemotherapy or radiotherapy). Thirty-four were at grade I, two hundred three at grade II, sixty-eight were at grade III, according to the grading system of the World Health Organization (WHO). Two hundred ten were squamous cell carcinoma and ninety-five were adenocarcinoma. Two hundred twenty-four were central type and eighty-one were peripheral type. From lymph node metastasis, consisted of one hundred twenty specimens of no metastasis and one hundred eighty-five of yes metastasis. Fifty were stage I, ninety were stage II, ninety-four were stage III and seventy-one were stage IV, according to clinical staging of pTNM, respectively.

\section{Immunohistochemistry}

All samples were fixed $10 \%$ buffered formalin and embedded in paraffin. $4 \mu \mathrm{m}$ thick tissue sections were cut. All sections were deparaffinnized and dehydrated with graded alcohol. The sections were then washed $10 \mathrm{~min}$ in phosphate-buffered saline (PBS) ( $\mathrm{pH}$ 7.2). The endogenous peroxidase activity was quenched by incubation in methanol containing $3 \% \mathrm{H} 2 \mathrm{O} 2$ for $10 \mathrm{~min}$ at room temperature, then heated for $30 \mathrm{~min}$ at $95^{\circ} \mathrm{C}$ to repair antigens and finally rinsed in PBS. After several washes in PBS, the sections were blocked with goat serum for $20 \mathrm{~min}$ at room temperature, and then incubated with mouse monoclonal CD133 (Santa Cruz) and CD34 (LabVision) primary antibodies overnight at $4^{\circ} \mathrm{C}$ in a humidified chamber. Replacing the primary antibodies by PBS, negative control staining was using performed, the slides were treated with polymer enhancer (Reagent A) for $20 \mathrm{~min}$ at room temperature. After a complete wash in PBS, the slides were treated with goat anti-mouse antibody (Reagent B) for $30 \mathrm{~min}$ at room temperature. After a complete wash in PBS, the slides were develop in freshly prepared diaminobenzedine solution (DAB,) for $8 \mathrm{~min}$, and then counterstained with hematoxylin, dehydrated, airdried, and mounted.

\section{Evaluation of score}

Slides were reviewed independently by two observers to evaluate the staining pattern of the protein separately under the light microscopy. In scoring expression of CD133 and CD34 protein, both the extent and intensity of immunopositivity were considered. The intensity of positivity was scored as follows: 0, negative; 1, weak; 2 , moderate; 3 , strong. The extent of positivity was scored according to the percentage of cells showing positive staining: $<10 \%$ is $1 ; 11 \%-50 \%$ is 2 ; $51 \%-75 \%$ is 3 ; $>75 \%$ is 4 . The final score was determined by multiplying the intensity of positivity and the extent of positivity scores, yielding a range from 0 to 12 . The expression for CD133 and CD34 was considered positive when the scores were $>1$.

The staining for CD133 was mainly confined to the cytoplasm and membrane. The staining for CD34 was mainly confined to the cytoplasm and membrane and presented as brown granular materials. Microvessel density (MVD) was determined by the mean number of small CD34-positive vessels counted. A modified Weidner's method was used to calculate the MVD of NSCLC by anti-CD34 immunostaining [42]. All samples were submitted for PAS-CD34 dual staining to characterize endothelial cells glycosylated basement membranes of vessels as well as vessel-like (VM) channels [43]. Moreover, no necrosis or hemorrhage in tumor tissue near the VM channels was noted. The technique was adopted from Yue et al. with some modifications [44]. The observers selected ten high power fields and counted individual microvessels.

\section{Statistical analysis}

Fisher's exact test, Pearson Chi-square test for trends in proportions, Spearman's correlation coefficient test, and Kaplan-Meier's method with log rank test or Cox Regression method for univariate or multivariate overall 
survival analysis were used to assess the associations among the positive staining of CD133 or VM or MVD and clinicopathological indices by SPSS 17.0 software for windows (Chicago, IL). A value of $\mathrm{P}<0.05$ was recognized as statistically significant.

\section{Results}

The association between expression of CD133, VM and MVD and clinicopathological factors

CD133 protein was expressed positively in $48.9 \%$ (149/ $305)$ of NSCLC and 26.7\% (8/30) of distal normal lung tissue. The staining for CD133 was confined to the membrane and cytoplasm. There was a significant difference between the NSCLC group and the distal normal lung tissue $(\mathrm{P}<0.05)$ (Figures 1,2 , and 3$)$. There was a significant difference between expression of CD133 and histological grade, pTNM stage and lymph node metastasis $(\mathrm{P}<0.001)$. None of the distal normal lung tissues contained VM (Figure 4). Small vessel-like structures in the tumor that were PAS-positive but CD34-negative were to be VM channels. The cells external to the lumen of the VM channels were positive for tumor cells, which indicated the channels were formed by NSCLC cells (Figure 5, 6, and 7). The presence as well as pattern (linear, tubular, and network) of VM channels were recorded in each case. VM was identified in NSCLC tissue from 109 (35.7\%) of 305 specimens of NSCLC. There was a significant difference between the NSCLC group and the distal normal lung group $(\mathrm{P}<0.05)$ (Table 1). And the positive staining of VM and MVD score were found to be closely linked to pTNM stages, grade of tumors, lymph node metastasis in NSCLC $(\mathrm{P}<0.05)$. However, the positive expression of CD133, $\mathrm{VM}$ and MVD score were no significant association with

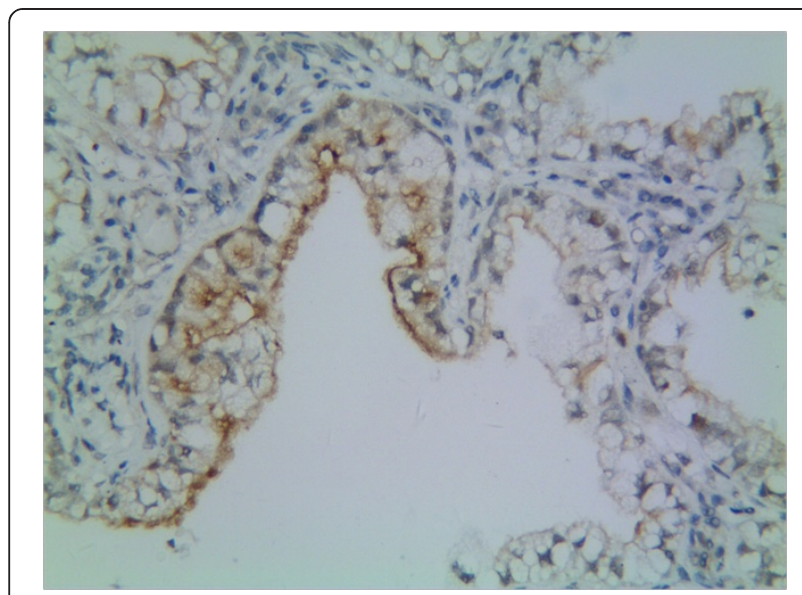

Figure 1 Representative results of CD133 protein in non-small cell lung cancer and control group. Control bronchiolar epithelial cells expressed CD133 in the membrane and cytoplasm.

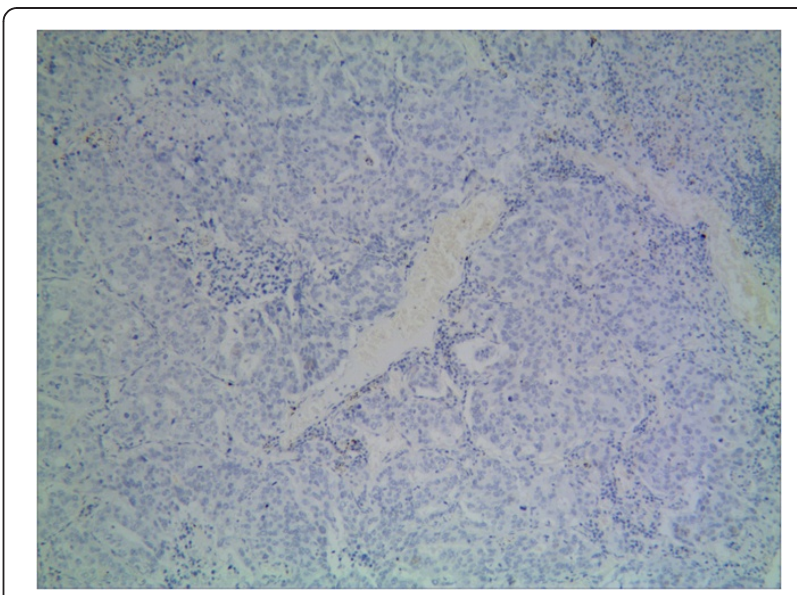

Figure 2 Representative results of CD133 protein in non-small cell lung cancer and control group. NSCLC cells did not express a detectable level of CD133.

gender, age, gross type, histological type and diameter of tumors $(\mathrm{P}>0.05)$ (Table 1$)$.

\section{Prognosis and multivariate analysis}

Follow-up data showed that a significantly decreasing trend in the overall mean survival time between the carcinomas with the expression of CD133 (19.0 months) and those without (58.1 months) $(\log$ rank=247.8, P < $0.001)$. The survival rate of the VM group was significantly less than the non-VM group $(\mathrm{P}<0.001)$; the survival rate of the $M V D<22$ group was significantly more than the $M V D \geq 22$ group (because the mean score of MVD was 22.0 \pm 11.2 ) (Figures 8, 9 and 10. CD133, VM, MVD, postoperative therapy and PTNM stages were independent prognostic factors by multivariate analysis $(\mathrm{P}<0.05))$ (Table 2).

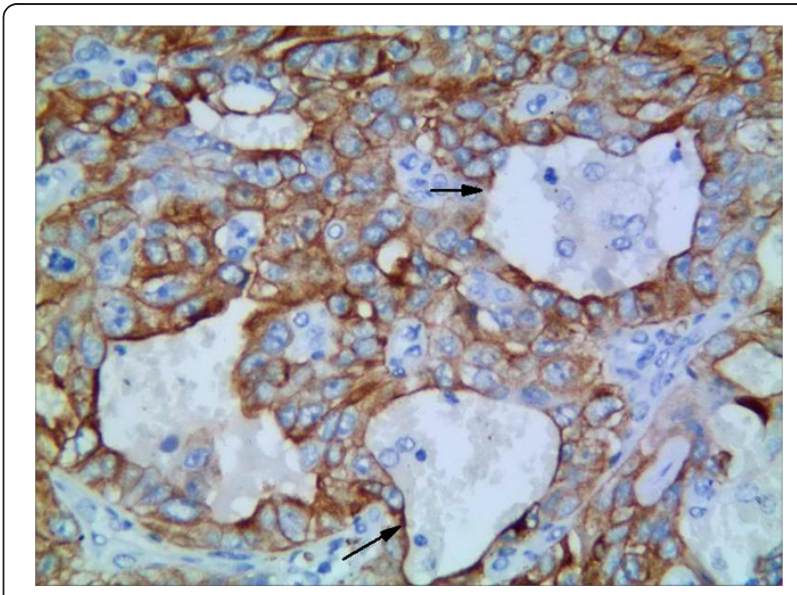

Figure 3 Representative results of CD133 protein in non-small cell lung cancer and control group. CD133 predominantly localized in the membrane and cytoplasm in moderately differentiated squamous cell carcinoma (grade 2) (CD133×400)(black arrow is VM). 


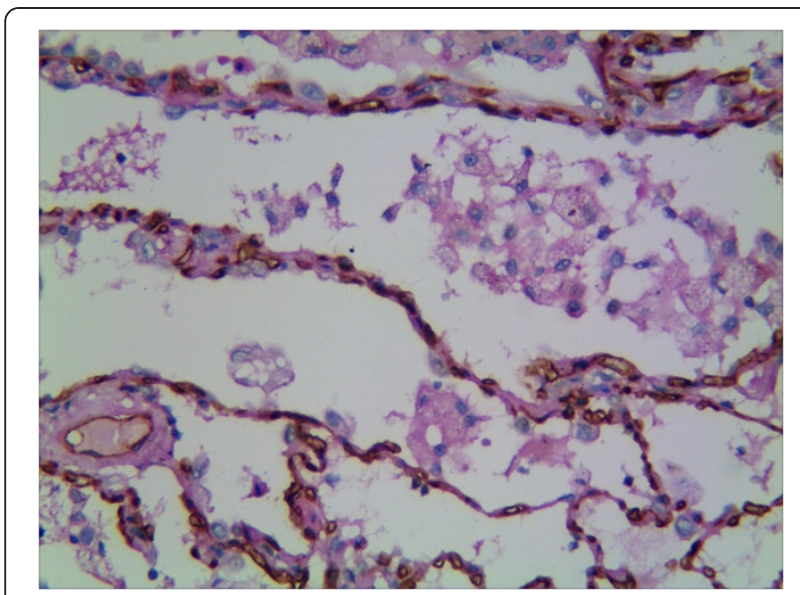

Figure 4 Representative results of VM in non-small cell lung cancer and control group. No VM's phenomenon in the control group.

\section{Correlation of CD133, VM and MVD in NSCLC}

In positive expression of CD133 group, the mean score of MVD was 29.4 \pm 9.8 ; in negative expression of CD133

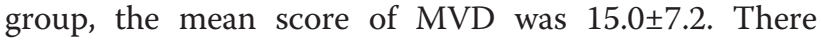
was a positive correlation between CD133 and MVD $(\mathrm{r}=0.685, \mathrm{P}<0.001)$, and the same correlation between VM and MVD $(r=0.777, \mathrm{P}<0.001)$. The positive correlation between $\mathrm{CD} 133$ and VM was found $(\mathrm{r}=0.585$, $\mathrm{P}<0.001)$.

\section{Discussion}

Cancer stem cells, also known as tumor initiating cells, are defined as a subset of tumor cells with the capacity to self-renewal and give rise to the differentiated cells that comprise the bulk of the tumor $[3,5,6,9,13,45]$. CD133 is commonly regarded as a marker of CSCs or

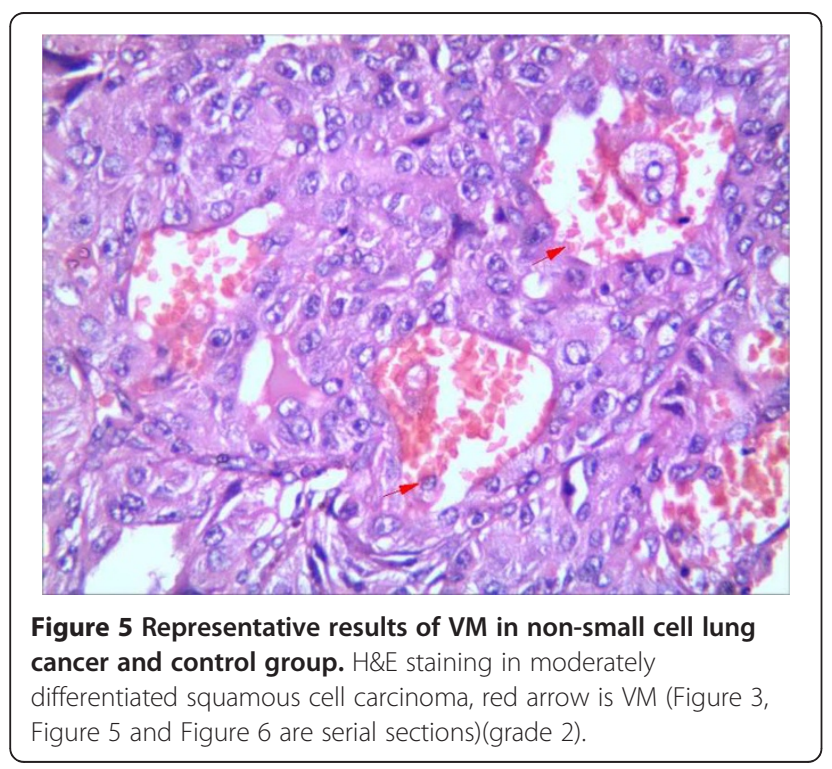

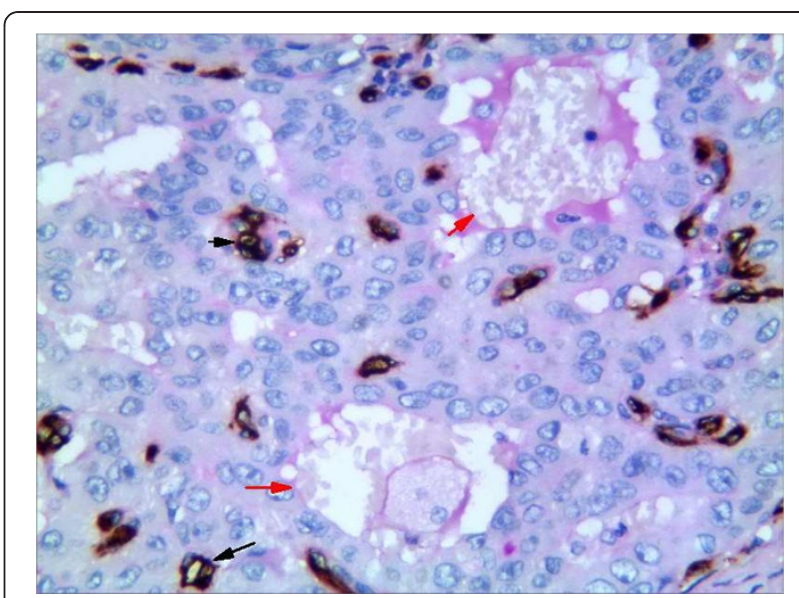

Figure 6 Representative results of VM in non-small cell lung cancer and control group. Endothelial cells are detected with antiCD34 immunhistochemistry staning (dark brown) and vascular basement membrane with PAS staining (purple magenta) (red arrow: vessel stained positively with PAS but negatively with CD34; black arrow: vessel stained positively with CD34).

TIC in many tumors [9,16-27]. Recently, CD133 has been identified in more or equal to $50 \%$ of NSCLC, colon, gastric and ovarian $[9,19,22,46]$. Lung cancer CD133+ cells were able to grow indefinitely as tumor spheres; upon differentiation, lung cancer CD133+ cells acquired the specific lineage markers, while loosed the tumorigenic potential together with CD133 expression [47]. Furthermore, CD133+ cancer cells were more efficient at forming clones and proliferated more extensively than the CD133- population [46]. Lung cancer stem cells are resistant to chemotherapeutic drugs, in line with the poor therapeutic effect of conventional chemotherapy on lung cancer patients [47]. Therefore, anti-CD133 gene-drug conjugates may warrant further evaluation as

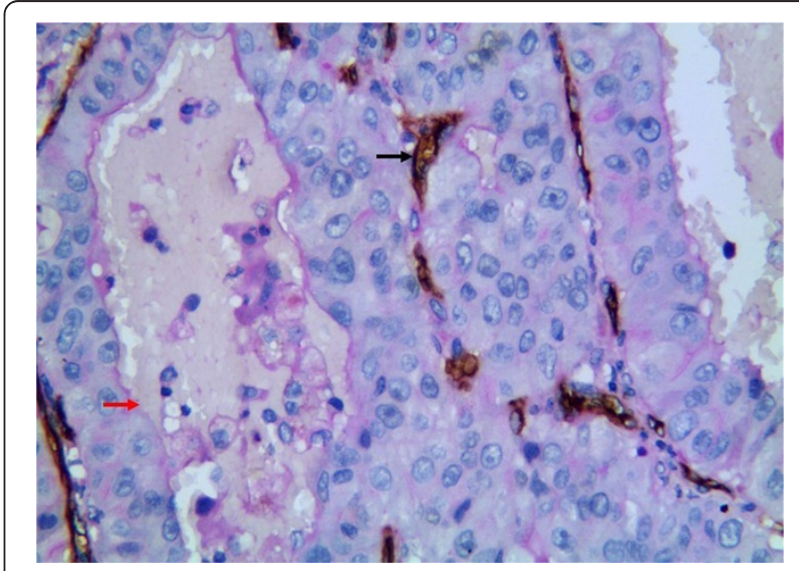

Figure 7 Representative results of VM in non-small cell lung cancer and control group. VM in moderately differentiated

squamous cell carcinoma (red arrow is vessel, black arrow is VM) (grade 2) (CD34+PAS $\times 400)$. 
Table 1 Correlation of CD133 expression and VM to clinicopathological characteristics in NSCLC

\begin{tabular}{|c|c|c|c|c|c|c|c|c|c|}
\hline \multirow[t]{2}{*}{ Variable } & \multicolumn{2}{|c|}{ CD133 } & \multirow{2}{*}{$\begin{array}{c}P \\
\text { value }\end{array}$} & \multicolumn{2}{|c|}{ VM } & \multirow{2}{*}{$\begin{array}{c}P \\
\text { value }\end{array}$} & \multicolumn{2}{|c|}{ MVD } & \multirow{2}{*}{$\begin{array}{c}P \\
\text { value }\end{array}$} \\
\hline & Negative & Positive & & Negative & Positive & & (mean) & $F$ & \\
\hline Tissue & & & $<0.05$ & & & $<0.001$ & & & \\
\hline Normal & 22 & 8 & & 0 & 30 & & & & \\
\hline NSCLC & 156 & 149 & & 196 & 109 & & & & \\
\hline Gender & & & $>0.05$ & & & $>0.05$ & & 0.154 & $>0.05$ \\
\hline Male & 117 & 116 & & 150 & 83 & & $22.2 \pm 11.3$ & & \\
\hline Female & 39 & 33 & & 46 & 26 & & $21.6 \pm 10.9$ & & \\
\hline$\underline{\text { Ages }}$ & & & $>0.05$ & & & $>0.05$ & & 0.476 & $>0.05$ \\
\hline$<60$ & 77 & 64 & & 93 & 48 & & $21.5 \pm 11.8$ & & \\
\hline$\geq 60$ & 79 & 85 & & 103 & 61 & & $22.4 \pm 10.7$ & & \\
\hline Gross type & & & $>0.05$ & & & $>0.05$ & & 0.004 & $>0.05$ \\
\hline Central & 114 & 110 & & 141 & 83 & & $22.0 \pm 11.6$ & & \\
\hline Peripheral & 42 & 39 & & 55 & 26 & & $21.9 \pm 10.1$ & & \\
\hline$\underline{\text { Histological type }}$ & & & $>0.05$ & & & $>0.05$ & & 3.550 & $>0.05$ \\
\hline Squamous carcinoma & 111 & 99 & & 141 & 69 & & $21.2 \pm 11.3$ & & \\
\hline Adenocarcinoma & 45 & 50 & & 55 & 40 & & $23.8 \pm 10.7$ & & \\
\hline Diameter of tumor & & & $>0.05$ & & & $>0.05$ & & 0.133 & $>0.05$ \\
\hline$<3.0 \mathrm{~cm}$ & 13 & 17 & & 20 & 10 & & $21.3 \pm 11.1$ & & \\
\hline$\geq 3.0 \mathrm{~cm}$ & 143 & 132 & & 176 & 99 & & $22.1 \pm 11.2$ & & \\
\hline Differentiation & & & $<0.001$ & & & $<0.001$ & & 31.231 & $<0.001$ \\
\hline Well & 30 & 4 & & 32 & 2 & & $13.6 \pm 7.1$ & & \\
\hline Moderate & 104 & 99 & & 142 & 61 & & $20.9 \pm 9.7$ & & \\
\hline Poor & 22 & 46 & & 22 & 46 & & $29.6 \pm 12.9$ & & \\
\hline$\underline{\text { Lymph node metastasis }}$ & & & $<0.001$ & & & $<0.001$ & & 67.650 & $<0.001$ \\
\hline Yes & 71 & 114 & & 93 & 92 & & $25.9 \pm 10.2$ & & \\
\hline No & 85 & 35 & & 103 & 17 & & $16.1 \pm 10.0$ & & \\
\hline pTNM stage & & & $<0.001$ & & & $<0.001$ & & 200.694 & $<0.001$ \\
\hline land II & 111 & 29 & & 129 & 11 & & $14.3 \pm 6.7$ & & \\
\hline III and IV & 45 & 120 & & 67 & 98 & & $28.5 \pm 10.1$ & & \\
\hline$\underline{\mathrm{VM}}$ & & & $<0.001$ & & & & & 471.458 & $<0.001$ \\
\hline Negative & 143 & 53 & & & & & $15.5 \pm 5.9$ & & \\
\hline Positive & 13 & 96 & & & & & $33.7 \pm 8.7$ & & \\
\hline$\underline{C D 133}$ & & & & & & $<0.001$ & & 216.747 & $<0.001$ \\
\hline Negative & & & & 143 & 13 & & $15.0 \pm 7.2$ & & \\
\hline Positive & & & & 53 & 96 & & $29.4 \pm 9.8$ & & \\
\hline
\end{tabular}

a molecular therapeutic strategy to eradicate CD133+ cancer cells in lung cancer. To our data, there are no reports about the prognostic significance and correlation between CD133 expression and VM in NSCLC. Using immunohistochemistry, we detect the expression of CD133 in 149 (48.9\%) and it is closely related to the worst prognosis of NSCLC. Further research shows that the expression of CD133 may be involved in grade of NSCLC, lymphoid node metastasis and pTNM stages. And the positive expression of CD133 indicates a shorter survival time. Our study is consistent with parts of previous studies in lung carcinoma [48-50]. Another result is that not only normal lung tissue (bronchiolar epithelial cells) but also cancer cell expresses CD133. Although CD133, which is the most accredited, is useful stem cell markers, it is known to be expressed also in nonstem cell populations and play an important role in tumorigenesis [51]. It has been shown that CD133 is an apical molecule in many normal human tissues and its expression is not restricted to stem cells in pancreatic 


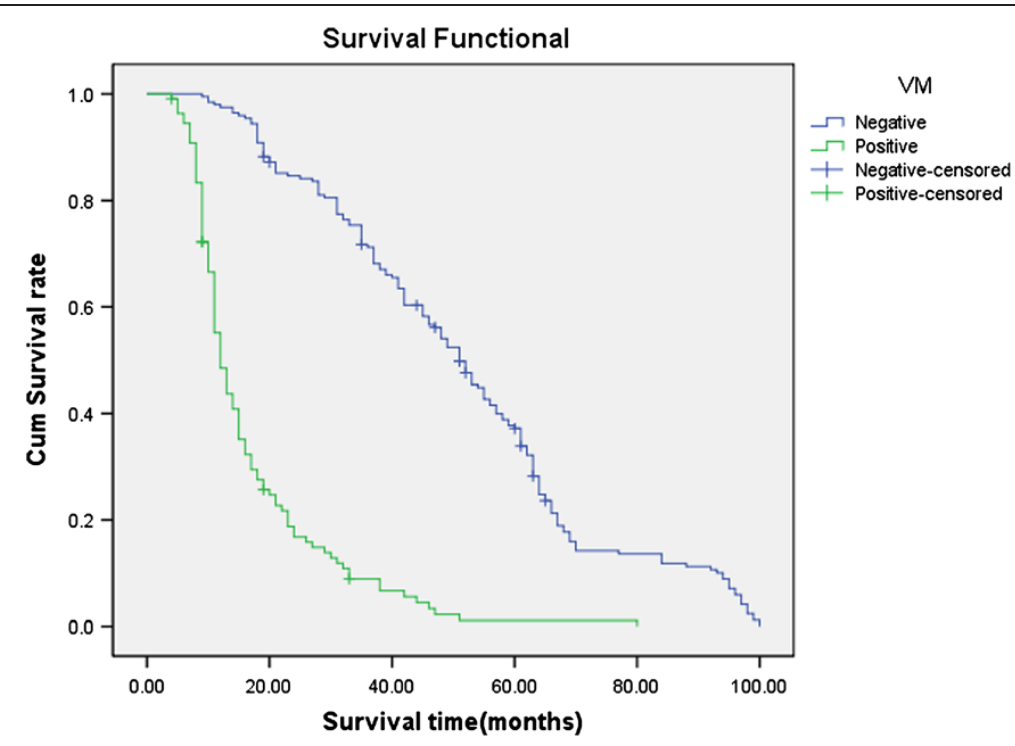

Figure 8 Kaplan-Meier survival analysis by CD133, VM and MVD status (A is CD133; B is VM; C is MVD). ( $n=305$ ). The $y$-axis represents the percentage of patients; the $x$-axis, their survival in months. the green line represents CD133+ patients with a trend of worse survival than the blue line representing CD133- non-small cell lung cancer patients $(P<0.001)$. Mean survival times were 19.0 months for the CD133+ group and 58.1 months for the CD133- group.

tissues [52]. In addition, CD133 has been taken as a prognostic factor of some cancers, such as colon carcinoma, non-small cell lung cancer, hepatocellular carcinoma and cholangiocarcinoma [48-51,53-55]. Our result is similar to the previous studies (including lung and other tissues) $[22,49,52,56]$. As the population of CD133+ cells in NSCLC may represent a relatively large portion of cells (up to $48.9 \%$ ) and only a part of CD133+ cells possesses the abilities of stem cells [47]. These cancer stem cells after routine chemo- and radio-therapy may lead to tumor recurrence and metastasis through the self-renewal, the multiple differentiating potential and the proliferating aptitude in line with cancer stem cell hypothesis [57].

Some highly aggressive human tumor cells mimic endothelial cells and form vascular channel-like structures to

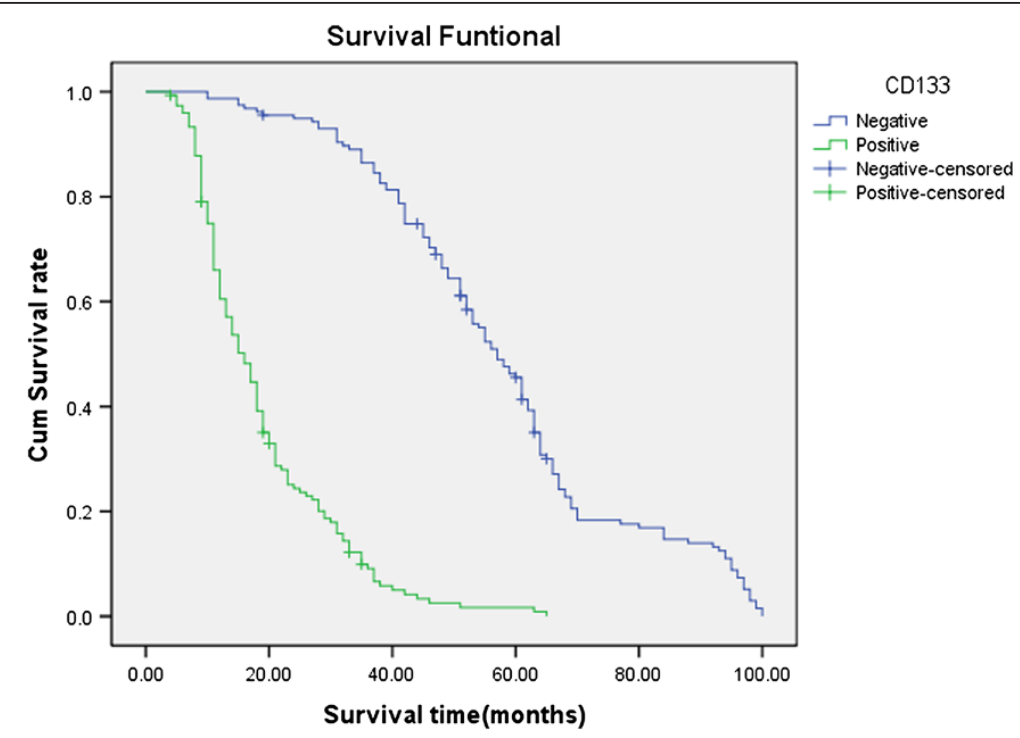

Figure 9 Kaplan-Meier survival analysis by CD133, VM and MVD status (A is CD133; B is VM; C is MVD). ( $n=305$ ). The $y$-axis represents the percentage of patients; the $x$-axis, their survival in months. The green line represents VM positive patients with a trend of worse survival than the blue line representing VM negative NSCLC patients $(P<0.001)$. Mean survival times were 16.9 months for the VM positive group and 51.4 months for the VM negative group. 


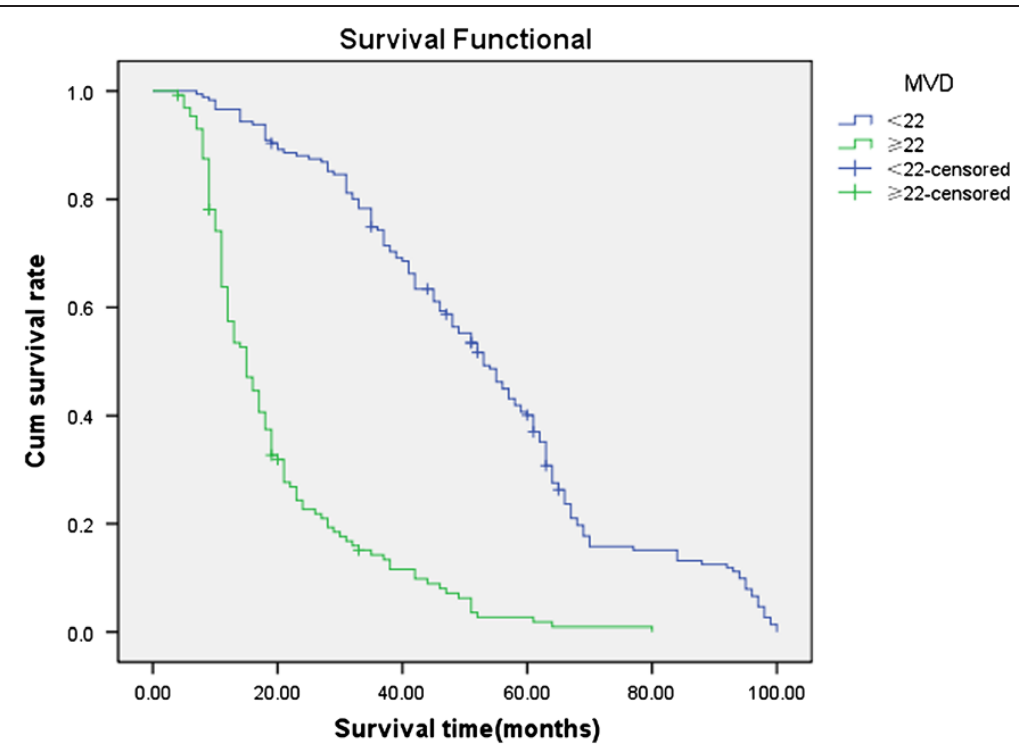

Figure 10 Kaplan-Meier survival analysis by CD133, VM and MVD status (A is CD133; B is VM; C is MVD). ( $\mathbf{n}=305$ ). The $y$-axis represents the percentage of patients; the $x$-axis, their survival in months. The green line represents MVD $\geq 22$ group(because the mean score of MVD is 22.0 ) with a trend of worse survival than the blue line representing MVD $<22$ group NSCLC patients $(P<0.001)$. Mean survival times were 19.8 months for $M V D \geq 22$ group and 53.2 months for $M V D<22$ group.

convey blood and nutrients without the participation of endothelial cells. In other words, the term VM is appropriate to describe the formation of these vascular channels by tumor cells. In the H\&E staining, we observe that VM channels are composed of a basement membrane with positive PAS staining and CD34- in the absence of endothelial cells. Based on PAS and CD34 staining, some morphologic patterns of $\mathrm{VM}$ including straight lines, arcs, loops, networks and patterns have been described [58]. In our study, VM is observed in 35.7\% (109/305) of NSCLC patients. And we find that VM is associated with grade of tumor, lymph node metastasis and pTNM stages, which are in agreement with previous reports $[59,60]$; further research, we find that the VM-positive-group correlates with the lower survival time, suggests that the existence of VM increases the likelihood of hematogenous metastases and is in inverse proportion to prognosis [34].

Microvessel density (MVD) is the standard method of measuring tumor angiogenesis and is closely related with tumor growth and postoperative prognosis. So the patients with high scores of MVD indicate early metastasis and

Table 2 Multivariate survival analysis of $\mathbf{3 0 5}$ patients with NSCLC

\begin{tabular}{lccccc}
\hline Covariate & B & SE & Sig & Exp(B) & 95\%Cl \\
\hline pTNM & 0.425 & 0.196 & 0.030 & 1.530 & $1.042-2.246$ \\
\hline VM & 0.649 & 0.226 & 0.004 & 1.914 & $1.229-2.982$ \\
\hline CD133 & 1.632 & 0.181 & 0.000 & 5.116 & $3.587-7.298$ \\
\hline MVD & 0.515 & 0.226 & 0.023 & 1.674 & $1.075-2.606$ \\
\hline Therapy & 0.325 & 0.162 & 0.045 & 0.723 & $0.526-0.992$ \\
\hline
\end{tabular}

short survival $[61,62]$. Our data is consistent with these results. CD133 is not expressed in all tumors, and expressed only a small fraction of the tumor cells in CD133-positive tumors. The niche where CSCs reside may regulate CSCs self-renewal. Vascular niche may regulate CSCs fate. Alternatively, perhaps CD133 is a marker that does not initiate but rather enhances tumor growth, for example, by means of better tumor vascularization [51]. Our research also shows that CD133, VM and MVD are positively correlated with each other in CD133positive population, suggesting that CSCs may be related to angiogenesis and vasculogenic mimicry. CSCs have selfrenewal properties, multiple differentiating potential and proliferating aptitude. Tumors require a blood and nutrient supply for growth and metastasis. When the diameter of tumor is more than $1 \mathrm{~mm} 3$ in volume, tumor can stimulate angiogenesis in order to get adequate blood, the $\mathrm{CD} 133$ positive cells may contribute to the formation of capillaries [62]. But when the blood supplied by neovascularization cannot meet the needs of tumor growth, some CSCs can mimic endothelial cells and form vascular channel-like structures, which is VM [63]. The microvessel and VM sustain CSCs self-renewal, multiple differentiating potential and proliferating aptitude. The combined detection of CD133, VM and MVD, to some extent, can reflect the biological behavior of NSCLC cells, thus giving the choice of molecular targeting therapy.

\section{Conclusions}

It is suggested that CD133 may play an important role in the evolution of NSCLC. And CD133, VM and MVD 
should be considered as potential marker for the prognosis in patients with NSCLC.

\section{Competing interests}

The authors declare that they have no competing interests.

\section{Authors' contributions}

WSW and TSY carried out the design, analysis of pathology and drafted the manuscript. YL, ZL, CDM, and ML carried out sample collections and coordination. WDN and CZN performed the immunohistochemical staining. All authors read and approved the manuscript.

\section{Acknowledgements}

This work was supported by the Anhui Province College Excellent Young Talents Found Project (2012SQRL095).

Received: 30 January 2012 Accepted: 14 November 2012

Published: 21 November 2012

\section{References}

1. Jemal A, Center MM, DeSantis C, Ward EM: Global patterns of cancer incidence and mortality rates and trends. Cancer Epidemiol Biomarkers Prev 2010, 19:1893-1907.

2. Ramalingam SS, Owonikoko TK, Khuri FR: Lung cancer: new biological insights and recent therapeutic advances. CA Cancer J Clin 2011, 61:91-112.

3. Reya T, Morrison SJ, Clarke MF, Weissman IL: Stem cells, cancer, and cancer stem cells. Nature 2001, 414:105-111.

4. Monk M, Holding C: Human embryonic genes re-expressed in cancer cells. Oncogene 2001, 20:8085-8091.

5. Singh SK, Hawkins C, Clarke ID, Squire JA, Bayani J, Hide T, Henkelman RM, Cusimano MD, Dirks PB: Identification of human brain tumour initiating cells. Nature 2004, 432:396-401.

6. Scadden DT: Cancer stem cells refined. Nat Immunol 2004, 5:701-703.

7. Ponti D, Costa A, Zaffaroni N, Pratesi G, Petrangolini G, Coradini D, Pilotti S, Pierotti MA, Daidone MG: Isolation and in vitro propagation of tumorigenic breast cancer cells with stem/progenitor cell properties. Cancer Res 2005, 65:5506-5511.

8. Yu J, Vodyanik MA, Smuga-Otto K, Antosiewicz-Bourget J, Frane JL, Tian S, Nie J, Jonsdottir GA, Ruotti V, Stewart R, Slukvin II, Thomson JA: Induced pluripotent stem cell lines derived from human somatic cells. Science 2007, 318:1917-1920.

9. O'Brien CA, Pollett A, Gallinger S, Dick JE: A human colon cancer cell capable of initiating tumour growth in immunodeficient mice. Nature 2007, 445:106-110.

10. Ricci-Vitiani L, Lombardi DG, Pilozzi E, Biffoni M, Todaro M, Peschle C, DeMaria R: Identification and expansion of human colon cancer-initiating cells. Nature 2007, 445:111-115.

11. Okita K, Ichisaka T, Yamanaka S: Generation of germline-competent induced pluripotent stem cells. Nature 2007, 448:313-317.

12. Park IH, Zhao R, West JA, Yabuuchi A, Huo H, Ince TA, Lerou PH, Lensch MW, Daley GQ: Reprogramming of human somatic cells to pluripotency with defined factors. Nature 2008, 451:141-146.

13. Chiba T, Kamiya A, Yokosuka O, Iwama A: Cancer stem cells in hepatocellular carcinoma: recent progress and perspective. Cancer Lett 2009, 286:145-153.

14. Yin AH, Miraglia S, Zanjani ED, Almeida-Porada G, Ogawa M, Leary AG, Olweus J, Kearney J, Buck DW: AC133, a novel marker for human hematopoietic stem and progenitor cells. Blood 1997, 90:5002-5012.

15. Miraglia S, Godfrey W, Yin AH, Atkins K, Warnke R, Holden JT, Bray RA, Waller EK, Buck DW: A novel five-transmembrane hematopoietic stem cell antigen: isolation, characterization, and molecular cloning. Blood 1997, 90:5013-5021

16. Niu CS, Li MW, Ni YF, Chen JM, Mei JM, Li J, Fu XM: Effect of all-trans retinoic acid on the proliferation and differentiation of brain tumor stem cells. J Exp Clin Cancer Res 2010, 29:113.

17. Friel $A M$, Zhang $L$, Curley MD, Therrien VA, Sergent $P A$, Belden $S E$, Borger DR, Mohapatra G, Zukerberg LR, Foster R, Rueda BR: Epigenetic regulation of CD133 and tumorigenicity of CD133 positive and negative endometrial cancer cells. Reprod Biol Endocrinol 2010, 8:147.

18. Sagrinati C, Netti GS, Mazzinghi B, Lazzeri E, Liotta F, Frosali F, Ronconi E, Meini C, Gacci M, Squecco R, Carini M, Gesualdo L, Francini F, Maggi E,
Annunziato F, Lasagni L, Serio M, Romagnani S, Romagnani P: Isolation and characterization of multipotent progenitor cells from the Bowman's capsule of adult human kidneys. J Am Soc Nephrol 2006, 17:2443-2456.

19. Janikova M, Skarda J, Dziechciarkova M, Radova L, Chmelova J, Krejci V, Sedlakova E, Zapletalova J, Langova K, Klein J, Grygarkova I, Kolek V: Identification of CD133+/Nestin + putative cancer stem cells in non-small cell lung cancer. Biomed Pap Med Fac Univ Palacky Olomouc Czech Repub 2010, 154:321-326.

20. Kordes C, Sawitza I, Müller-Marbach A, Ale-Agha N, Keitel V, KlonowskiStumpe H, Häussinger D: CD133+ hepatic stellate cells are progenitor cells. Biochem Biophys Res Commun 2007, 352:410-417.

21. Yang ZL, Zheng Q, Yan J, Pan Y, Wang ZG: Upregulated CD133 expression in tumorigenesis of colon cancer cells. World I Gastroenterol 2011, 17:932-937.

22. Zhao P, Li Y, Lu Y: Aberrant expression of CD133 protein correlates with $\mathrm{Ki}-67$ expression and is a prognostic marker in gastric adenocarcinoma. BMC Cancer 2010, 10:218.

23. Zou J, Yu XF, Bao ZJ, Dong J: Proteome of human colon cancer stem cells: a comparative analysis. World Gastroenterol 2011, 17:1276-1285.

24. Moriyama T, Ohuchida K, Mizumoto K, Cui L, Ikenaga N, Sato N, Tanaka M: Enhanced cell migration and invasion of CD133+ pancreatic cancer cells cocultured with pancreatic stromal cells. Cancer 2010, 116:3357-3368.

25. Wang XY, Penalva LO, Yuan H, Linnoila Rl, Lu J, Okano H, Glazer Rl: Musashi1 regulates breast tumor cell proliferation and is a prognostic indicator of poor survival. Mol Cancer 2010, 9:221.

26. Ito Y, Hamazaki TS, Ohnuma K, Tamaki K, Asashima M, Okochi H: Isolation of murine hair-inducing cells using the cell surface marker prominin-1/CD133. J Invest Dermatol 2007, 127:1052-1060.

27. Rentala S, Yalavarthy PD, Mangamoori LN: Alpha1 and beta1 integrins enhance the homing and differentiation of cultured prostate cancer stem cells. Asian J Androl 2010, 12:548-555.

28. Folkman J, Klagsbrun M: Angiogenic factors. Science 1987, 235:442-447.

29. Maniotis A, Folberg R, Hess A, Seftor EA, Gardner LM, Pe'er J, Trent JM, Meltzer PS, Hendrix MJ: Vascular channel formation by human melanoma cells in vivo and in vitro: vasculogenic mimicry. Am J Pathol 1999, 155:739-752.

30. Forberg R, Hendrix MJ, Maniotis AJ: Vasculogenic mimicry and tumor angiogenesis. Am J Pathol 2000, 156:361-381.

31. Zhang S, Guo H, Zhang D, Zhang W, Zhao X, Ren Z, Sun B: Microcirculation patterns in different stages of melanoma growth. Onclo Rep 2006, 15:15-20.

32. Fan $\mathrm{YZ}$, Sun $\mathrm{W}$ : Molecular regulation of vasculogenic mimicry in tumors and potential tumor-target therapy. World J Gastrointest Surg 2010, 2:117-127.

33. Sun $W$, Fan $Y Z$, Zhang $W Z$, Ge CY: A pilot histomorphology and hemodynamic of vasculogenic mimicry in gallbladder carcinomas in vivo and in vitro. J Exp Clin Cancer Res 2011, 30:46.

34. Shirakawa K, Wakasugi H, Heike Y, Watanabe I, Yamada S, Saito K, Konishi F: Vasculogenic mimicry and pseudo-comedo formation in breast cancer. Int J Cancer 2002, 99:821-828.

35. Wu N, Zhao X, Liu M, Liu H, Yao W, Zhang Y, Cao S, Lin X: Role of microRNA-26b in glioma development and its mediated regulation on EphA2. PLoS One 2011, 6:e16264.

36. Liu W, Xu G, Ma J, Jia W, Li J, Chen K, Wang W, Hao C, Wang Y, Wang X: Osteopontin as a key mediator for vasculogenic mimicry in hepatocellular carcinoma. Tohoku J Exp Med 2011, 224:29-39.

37. Vartanian AA, Stepanova EV, Gutorov SL, Solomko ES, Grigorieva IN, Sokolova IN, Baryshnikov AY, Lichinitser MR: Prognostic significance of periodic acid-schiff-positive patterns in clear cell renal cell carcinoma. Can J Urol 2009, 16:4726-4732.

38. Wang W, Lin P, Han C, Cai W, Zhao X, Sun B: Vasculogenic mimicry contributes to lymph node metastasis of laryngeal squamous cell carcinoma. J Exp Clin Cancer Res 2010, 29:60

39. Zhu P, Ning Y, Yao L, Chen M, Xu C: The proliferation, apoptosis, invasion of endothelial-like epithelial ovarian cancer cells induced by hypoxia. J Exp Clin Cancer Res 2010, 29:124.

40. Li M, Gu Y, Zhang Z, Zhang S, Zhang D, Saleem AF, Zhao X, Sun B: Vasculogenic mimicry: a new prognostic sign of gastric adenocarcinoma. Pathol Oncol Res 2010, 16:259-266.

41. Gray DR, Huss WJ, Yau JM, Durham LE, Werdin ES, Funkhouser WK Jr, Smith GJ: Short-term human prostate primary xenografts: an in vivo model of human prostate cancer vasculature and angiogenesis. Cancer Res 2004, 64:1712-1721.

42. Kumada T, Tsuneyama K, Hatta H, Ishizawa S, Takano Y: Improved 1-h rapid immunostaining method using intermittent microwave irradiation: 
practicability based on 5 years application in Toyama Medical and Pharmaceutical University Hospital. Mod Pathol 2004, 17:1141-1149.

43. Ahmadi SA, Moinfar M, Gohari Moghaddam K, Bahadori M: Practical application of angiogenesis and vasculogenic mimicry in prostatic adenocarcinoma. Arch Iran Med 2010, 13:498-503.

44. Yue WY, Chen ZP: Does vasculogenic mimicry exist in astrocytoma? J Histochem Cytochem 2005, 53:997-1002.

45. Rosen JM, Jordan $\mathrm{CT}$ : The increasing complexity of the cancer stem cell paradigm. Science 2009, 324:1670-1673.

46. Ferrandina G, Bonanno G, Pierelli L, Perillo A, Procoli A, Mariotti A, Corallo M, Martinelli E, Rutella S, Paglia A, Zannoni G, Mancuso S, Scambia G: Expression of CD133-1 and CD133-2 in ovarian cancer. Int J Gynecol Cancer 2008, 18:506-514.

47. Eramo A, Lotti F, Sette G, Pilozzi E, Biffoni M, Di Virgilio A, Conticello C, Ruco L, Peschle C, De Maria R: Identification and expansion of the tumorigenic lung cancer stem cell population. Cell Death Differ 2008, 15:504-514.

48. Xu YH, Zhang GB, Wang JM, Hu HC: B7-H3 and CD133 expression in non-small cell lung cancer and correlation with clinicopathologic factors and prognosis. Saudi Med J 2010, 31:980-986.

49. Woo T, Okudela K, Mitsui H, Yazawa T, Ogawa N, Tajiri M, Yamamoto T, Rino Y, Kitamura H, Masuda M: Prognostic value of CD133 expression in stage I lung adenocarcinomas. Int I Clin Exp Pathol 2010, 4:32-42.

50. Salnikov AV, Gladkich J, Moldenhauer G, Volm M, Mattern J, Herr I: CD133 is indicative for a resistance phenotype but does not represent a prognostic marker for survival of non-small cell lung cancer patients. Int J Cancer 2010, 126:950-958.

51. Schneider M, Huber J, Hadaschik B, Siegers GM, Fiebig HH, Schüler J: Characterization of colon cancer cells: a functional approach characterizing CD133 as a potential stem cell marker. BMC Cancer 2012, 12:96.

52. Immervoll H, Hoem D, Sakariassen PØ, Steffensen OJ, Molven A: Expression of the "stem cell marker" CD133 in pancreas and pancreatic ductal adenocarcinomas. BMC Cancer 2008, 8:48.

53. Horst D, Kriegl L, Engel J, Kirchner T, Jung A: CD133 expression is an independent prognostic marker for low survival in colorectal cancer. $\mathrm{Br} J$ Cancer 2008, 99:1285-1289.

54. Song W, Li H, Tao K, Li R, Song Z, Zhao Q, Zhang F, Dou K: Expression and clinical significance of the stem cell marker CD133 in hepatocellular carcinoma. Int J Clin Pract 2008, 62:1212-1218.

55. Fan L, He F, Liu H, Zhu J, Liu Y, Wang L, Guo Y, Wang Z, Yan Q, Huang G: CD133: a potential indicator for differentiation and prognosis of human cholangiocarcinoma. BMC Cancer 2011, 11:320.

56. Karbanová J, Missol-Kolka E, Fonseca AV, Lorra C, Janich P, Hollerová H, Jászai J, Ehrmann J, Kolár Z, Liebers C, Arl S, Subrtová D, Freund D, Mokry J, Huttner WB, Corbeil D: The stem cell marker CD133 (Prominin-1) is expressed in various human glandular epithelia. J Histochem Cytochem 2008, 56:977-993.

57. Leta K, Tanaka F, Haraguchi N, Kita Y, Sakashita H, Mimori K, Matsumoto T, Inoue $\mathrm{H}$, Kuwano $\mathrm{H}$, Mori M: Biological and genetic characteristics of tumor-initiating cells in colon cancer. Ann Surg Oncol 2008, 15:638-648.

58. Folberg R, Maniotis AJ: Vasculogenic mimicry. APMIS 2004, 112:508-525.

59. Sun B, Qie S, Zhang S, Sun T, Zhao X, Gao S, Ni C, Wang X, Liu Y, Zhang L: Role and mechanism of vasculogenic mimicry in gastrointestinal stromal tumors. Hum Pathol 2008, 39:445-451.

60. Han C, Sun B, Wang W, Cai W, Lou D, Sun Y, Zhao X: Overexpression of microtubule-associated protein-1 light chain 3 is associated with melanoma metastasis and vasculogenic mimicry. Tohoku J Exp Med 2011, 223:243-251.

61. Mineo TC, Ambrogi V, Baldi A, Rabitti C, Bollero P, Vincenzi B, Tonini G: Prognostic impact of VEGF, CD31, CD34 and CD105 expression and tumor vessel invasion after radical surgery for IB-IIA non-small cell lung cancer. J Clin Pathol 2004, 57:591-597.

62. Hilbe W, Dirnhofer S, Oberwasserlechner F, Schmid T, Gunsilius E, Hilbe G, Wöll E, Kähler CM: CD133 positive endothelial progenitor cells contribute to the tumour vasculature in non-small cell lung cancer. J Clin Pathol 2004, 57:965-969.

63. El Hallani S, Boisselier B, Peglion F, Rousseau A, Colin C, Idbaih A, Marie Y, Mokhtari K, Thomas JL, Eichmann A, Delattre JY, Maniotis AJ, Sanson M: A new alternative mechanism in glioblastoma vascularization: tubular vasculogenic mimicry. Brain 2010, 133:973-982.

doi:10.1186/1471-2407-12-535

Cite this article as: Wu et al:: Aberrant expression of CD133 in non-small cell lung cancer and its relationship to vasculogenic mimicry. $B M C$ Cancer 2012 12:535.

\section{Submit your next manuscript to BioMed Central and take full advantage of:}

- Convenient online submission

- Thorough peer review

- No space constraints or color figure charges

- Immediate publication on acceptance

- Inclusion in PubMed, CAS, Scopus and Google Scholar

- Research which is freely available for redistribution 